DOI:

УДК 669.046.516:669.131.7

А.П. Єременко, к.т.н., доцент

Є.В. Колєснік, к.Т.н., доцент

Г.О. Сіваєва, студентка

О.О. Вовк, студентка

Дніпровський державний технічний університет, м. Кам'янське

\title{
МОДЕЛЮВАННЯ ОПТИМАЛЬНОГО СКЛАДУ МОДИФІКАТОРА ДЛЯ ОТРИМАННЯ ВИЛИВКІВ ІЗ ВИСОКОМІЦНОГО ЧАВУНУ БЕЗ ВИБІЛЕННЯ I ТЕРМІЧНОЇ ОБРОБКИ
}

В роботі наведені результати досліджень впливу складу графітизуючого модифікатора для обробки високоміиного чавуну з використанням методів планування експерименту. Підвищити ефективність модифікування, механічних властивостей чавуну і забезпечити отримання чавуну з необхідною мікроструктуру без використання термічної обробки можна за рахунок введення до складу модифікатора активних елементів. За результатами досліджень можна зробити висновок, що найбільш ефективними та недорогими елементами для введення до складу модифікатора є кальиій і барій.

Ключові слова: моделювання; модифікатор; високоміцний чавун; мікроструктура; вибілення; иементит; термічна обробка.

The results of research on the influence of the composition of the graphitizing modifier for the treatment of high-strength pig iron with the use of experimental design methods are given. Increase the efficiency of modification, mechanical properties of pig iron and to ensure that iron with the necessary microstructure without the use of heat treatment can be achieved by introducing into the modifier of active elements. According to the research results, it can be concluded that the most effective and inexpensive elements for introducing the modifier are calcium and barium.

Keywords: modeling; modifier; high-strength cast iron; microstructure; bleaching; cementite; thermal treatment.

\section{Постановка проблеми}

Однією із характерних особливостей високоміцного чавуну є кристалізація за метастабільною системою, що значно погіршує властивості тонкостінних виливків машинобудівного призначення. Присутність вільного цементиту в структурі чавуну є браковочною ознакою для більшості виливків машинобудівного призначення, так як це значно підвищує твердість, яка може перевищувати допустимі межі і ускладнювати механічну обробку литих заготовок в механічних цехах. Для усунення цього недоліку - усунення цементиту і отримання необхідної структури виливки проходять графітизуючу термообробку. Проведення термічної обробки вимагає виконання додаткових операцій і встаткування, виробничих площ, подовжує виробничий цикл виготовлення виливків, набагато збільшує енерговитратність й вартість лиття, що робить його неконкурентноздатним на ринку продукції. Для усунення цих недоліків були проведені дослідження одержання виливків без структурно вільного цементиту в литому стані за рахунок додаткового графітизуючого модифікування.

\section{Формулювання мети дослідження}

Метою роботи є розробка оптимального складу графітизуючого модифікатора, який при невеликих витратах забезпечує отримання виливків із високоміцного чавуну 3 необхідною структурою без термічної обробки.

\section{Виклад основного матеріалу}

При виробництві виливків із високоміцного чавуну для запобігання кристалізації з вибіленням у виливках застосовують вторинне модифікування феросиліцієм ФС75. Однак його використання в необхідних кількостях не завжди можливе із-за обмежень по кінцевому вмісту 
кремнію в чавуні. Підвищити графітизуючий потенціал феросплаву і зменшити його витрати можна за рахунок введення до його складу елементів-графітизаторів - A1, Ca, Ba, Ті. РЗМ. Ці елементи мають високу спорідненість до складових чавуну навіть при високих температурах, а з’єднання, що утворюються можуть бути підкладенками для зародків включень графіту.

Хімічний склад і витрата графітизуючого модифікатора відповідав умовам таблиці 1. Виплавку графітизуючого модифікатора проводили в електричній печі опору із графітовим нагрівачем ТГВІ в алундовому тиглі в атмосфері інертного газу. Для виплавки модифікатора використовувалися ті ж матеріали що й для виплавки чавуну Оцінювання впливу складу й витрати модифікатора на кристалізацію чавуну виконували по глибині вибілення в клиновій пробі і структурі чавуну в пробах різної товщини.

Використання промислового феросиліцію ФС 75 з добавками одного із активних елементів не забезпечувало одержання виливків 3 необхідною структурою й механічними властивостями, особливо за пластичними показниками в перетині виливків менше 16 мм. Тому для одержання необхідних властивостей виливки додатково спрямовувалися на термічну обробку. Для усунення цих недоліків (гальмування утворення карбідів, зниження твердості, подрібнення включень графіту, підвищення пластичних властивостей чавуну в литому стані) були проведені плавки з оптимізації складу модифікатора із використанням методу математичного планування експерименту.

Для побудови локальної математичної моделі залежності глибини вибілення від складу графітизуючого модифікатора був проведений повний факторний експеримент типу ПФП $2^{\mathrm{k}}[1]$. Інтервали варіювання й основні рівні факторів представлені в табл. 1, де "+" верхній рівень, "-" нижній рівень, "0" основний рівень значення фактора. Матриця планування й результати експериментів наведені в табл. 2.

Таблиия 1. Рівні факторів і інтервали варіювання

\begin{tabular}{|l|c|c|c|c|}
\hline \multicolumn{1}{|c|}{ Фактори } & $\begin{array}{c}\text { Основний } \\
\text { рівень }\end{array}$ & $\begin{array}{c}\text { Інтервал } \\
\text { варіювання }\end{array}$ & $\begin{array}{c}\text { Верхній } \\
\text { рівень }\end{array}$ & $\begin{array}{c}\text { Нижній } \\
\text { рівень }\end{array}$ \\
\hline$X_{1}$ вміст кальцію в модифікаторі, \% & 7 & 2 & 9 & 5 \\
\hline$X_{2}$ вміст барію в модифікаторі, \% & 7 & 2 & 9 & 5 \\
\hline$X_{e}$ витрата модифікатора, \% & 0.4 & 0.1 & 0.5 & 0.3 \\
\hline
\end{tabular}

Таблиия 2. Матриця планування експерименту ПФП-23

\begin{tabular}{|c|c|c|c|c|}
\hline № досліду & $X_{1}$ & $X_{2}$ & $X_{3}$ & $H_{\text {виб }}$ \\
\hline 1 & +9 & +9 & +0.5 & 24 \\
\hline 2 & -7 & +9 & +0.5 & 30 \\
\hline 3 & +9 & -7 & +0.5 & 18 \\
\hline 4 & -7 & -7 & +0.5 & 14 \\
\hline 5 & +9 & +9 & -0.3 & 33 \\
\hline 6 & -7 & +9 & -0.3 & 17 \\
\hline 7 & +9 & -7 & -0.3 & 25 \\
\hline 8 & -7 & -7 & -0.3 & 16 \\
\hline
\end{tabular}

За отриманими результатами після реалізації умов за планом повного факторного експерименту в кодовому масштабі була побудована локальна математична модель залежності глибини вибілення в клиновій пробі від складу модифікатора

$$
\begin{gathered}
H=28.125+2.875 X_{1}+3.875 X_{2}+0.625 X_{3}-0.375 X_{1} X_{2}-3.375 X_{1} X_{3}+ \\
+1.625 X_{2} X_{3}-2.125 X_{1} X_{2} X_{3} .
\end{gathered}
$$

Отримана математична модель після виключення малозначимих коефіцієнтів дала можливість визначити напрямок руху по градієнту в напрямку до області оптимуму. Враховуючи 
обмеження по витраті вторинного модифікатора для високоміцного чавуну цей показник був зафіксований на рівні не більше 0,35 \%. В табл. 3 приведені розраховані умови проведення експериментів руху по градієнту.

Таблиия 3. Розрахунки руху по градієнту

\begin{tabular}{|l|c|c|c|c|}
\hline \multicolumn{1}{|c|}{ Фактори } & $X_{1}$ & $X_{2}$ & $X_{3}$ & Глибина вибілення, мм \\
\hline Нульовий рівень & 7 & 7 & 0.4 & \\
\hline Інтервал варіювання & 2 & 2 & 0.1 & \\
\hline Коефіцієнт регресії & 2.875 & 3.875 & 0.625 & \\
\hline$b_{\mathrm{i} *} \delta_{\mathrm{i}}$ & 5.75 & 7.75 & 0.0625 & \\
\hline$\delta_{\text {iн }}$ & 1 & 1.5 & 0.06 & \\
\hline Округлення & 1 & 1.5 & 0 & \\
\hline Досліди: & & & & \\
\hline 1 (уявний) & 6 & 5.5 & 0.35 & \\
\hline 2 & 5 & 4.0 & 0.35 & 12 \\
\hline 3 & 4 & 2.5 & 0.35 & 10 \\
\hline 4 & 3 & 1 & 0.35 & \\
\hline
\end{tabular}

Після реалізації цих дослідів було прийняте рішення припинити рух по градієнту й описати поверхню функції відгуку навколо точки 3. Найменша глибина вибілення (7 мм) отримана при вмісті кальцію $4 \%$ і барію $2.5 \%$ у модифікаторі, при його витраті $0.35 \%$. Ці умови були прийняті за нульовий рівень У табл. 4 наведена матриця планування й умови проведення дослідів у новій області факторного простору.

Таблищя 4. Вивчення області оптимуму (І серія дослідів)

\begin{tabular}{|c|r|c|c|c|}
\hline Інтервал варіювання й рівні факторів & \multicolumn{1}{|c|}{$X_{1}$} & \multicolumn{1}{|c|}{$X_{2}$} & \multicolumn{1}{c|}{$X_{3}$} & $Y$ \\
\hline Нульовий рівень $X=$ & 4 & 2.5 & 0.35 & \\
\hline Інтервал варіювання & 1 & 1 & 0.05 & \\
\hline Верхній рівень & 5 & 3.5 & 0.4 & \\
\hline Нижній рівень & 3 & 1.5 & 0.3 & \\
\hline Досліди: & & & & \\
\hline 1 & + & + & + & 11 \\
\hline 2 & - & + & + & 15 \\
\hline 3 & + & - & + & 14 \\
\hline 4 & - & - & + & 14 \\
\hline 5 & + & + & - & 13 \\
\hline 6 & - & + & - & 19 \\
\hline 7 & + & - & - & 16 \\
\hline 8 & - & - & - & 17 \\
\hline
\end{tabular}

Розрахунки за результатами дослідів дали наступні значення коефіцієнтів регресії $b_{0}=15 ; b_{1}=-1.375 ; b_{2}=0.375 ; b_{3}=-1.375$

по яких можна записати лінійну модель

$$
H=15-1.375 X_{1}-0.375 X_{2}-1.375 X_{3} .
$$

Для уточнення моделі скористалися ортогональним планом другого порядку. Досліди, виконані за планом табл. 4, використовували в якості ядра планування, доповнивши дослідами на відстані $d$ від центру й на нульовому рівні. Умови проведення дослідів визначали за даними табл. 5. 
Таблиия 5. Дані для визначення умов дослідів

\begin{tabular}{|c|c|c|c|}
\hline Рівень факторів & $X_{1}$ & $X_{2}$ & $X_{3}$ \\
\hline Нульова крапка & 4 & 2.5 & 0.35 \\
\hline Зоряні точки & & & \\
\hline$X=-d$ & 2.8 & 1.3 & 0.29 \\
\hline$X=+d$ & 5.2 & 3.8 & 0.4 \\
\hline
\end{tabular}
табл. 6.

Результати дослідів, що становлять ортогональний план другого порядку, зведені в

Таблиия 6. Умови й результати дослідів за планом другого порядку

\begin{tabular}{|l|c|c|c|c|c|c|c|c|c|c|c|}
\hline Дослід & $X_{1}$ & $X_{2}$ & $X_{3}$ & $\tilde{O}_{1}^{2}-11 / 15$ & $\tilde{O}_{2}^{2}-11 / 15$ & $\tilde{O}_{3}^{2}-11 / 15$ & $X_{1} X_{2}$ & $X_{1} X_{3}$ & $X_{2} X_{3}$ & $Y$ & $Y_{\text {ро3 }}$ \\
\hline 1 & + & + & + & $4 / 15$ & $4 / 15$ & $4 / 15$ & + & + & + & 11 & 10,1 \\
\hline 2 & - & + & + & $4 / 15$ & $4 / 15$ & $4 / 15$ & - & - & + & 15 & 153 \\
\hline 3 & + & - & + & $4 / 15$ & $4 / 15$ & $4 / 15$ & - & + & - & 14 & 13,1 \\
\hline 4 & - & - & + & $4 / 15$ & $4 / 15$ & $4 / 15$ & + & + & - & 14 & 13,3 \\
\hline 5 & + & + & - & $4 / 15$ & $4 / 15$ & $4 / 15$ & + & - & - & 13 & 13,3 \\
\hline 6 & - & + & - & $4 / 15$ & $4 / 15$ & $4 / 15$ & - & - & - & 19 & 17,9 \\
\hline 7 & + & - & - & $4 / 15$ & $4 / 15$ & $4 / 15$ & - & + & + & 16 & 15,3 \\
\hline 8 & - & - & - & $4 / 15$ & $4 / 15$ & $4 / 15$ & + & - & + & 17 & 17,7 \\
\hline 9 & $-1,215$ & 0 & 0 & $23 / 30$ & $-11 / 15$ & $-11 / 15$ & 0 & 0 & 0 & 11 & 11,1 \\
\hline 10 & $+1,215$ & 0 & 0 & $23 / 30$ & $-11 / 15$ & $-11 / 15$ & 0 & 0 & 0 & 9 & 9,5 \\
\hline 11 & 0 & $-1,215$ & 0 & $-11 / 15$ & $23 / 30$ & $-11 / 15$ & 0 & 0 & 0 & 12 & 12,4 \\
\hline 12 & 0 & $+1,215$ & 0 & $-11 / 15$ & $23 / 30$ & $-11 / 15$ & 0 & 0 & 0 & 8 & 9,7 \\
\hline 13 & 0 & 0 & $-1,215$ & $-11 / 15$ & $-11 / 15$ & $23 / 30$ & 0 & 0 & 0 & 9 & 10,6 \\
\hline 14 & 0 & 0 & $+1,215$ & $-11 / 15$ & $-11 / 15$ & $23 / 30$ & 0 & 0 & 0 & 7 & 7,7 \\
\hline 15 & 0 & 0 & 0 & $-11 / 15$ & $-11 / 15$ & $-11 / 15$ & 0 & 0 & 0 & 9 & 6,7 \\
\hline
\end{tabular}

Користуючись даними табл. 6, визначали значення коефіцієнтів регресії для рівняння. За цими даними рівняння може бути записане у вигляді

$$
\begin{gathered}
H=12.266-1.226 X_{1} 1.082 X_{2} 1.214 X_{3} 1.125 X_{1} X_{2}+1.125 X_{1} X_{3}- \\
-0.125 X_{2} X_{3}+2.05\left(X_{1} 11 / 15\right)+2.05\left(X_{2} 11 / 15\right)+1.80\left(X_{3} 11 / 15\right) .
\end{gathered}
$$

При переході до звичайної форми запису:

Рівняння прийняло вид:

$$
b_{0}=12.266-11 / 15(2.05+2.05+1.80)=6.597 .
$$

$$
H=8.6-1.2 X_{1} 1.1 X_{2}-1.2 X_{3}-1.4 X_{1} X_{2}-1.4 X_{1} X_{3}+2 X_{12}+2 X_{22}+1.7 X_{32} .
$$

Для визначення координат оптимальної точки $C$ необхідно перенести нульову точку координат в екстремальну точку $C$. Екстремальні значення визначають із умови:

$$
\frac{\delta \mathrm{y}}{\delta \mathrm{x}_{1}}=\frac{\delta \mathrm{y}}{\delta \mathrm{x}_{2}}=\frac{\delta \mathrm{y}}{\delta \mathrm{x}_{3}}=0 .
$$

Для визначення оптимальних умов протікання процесу графітизуючого модифікування отримане рівняння другому ступеня необхідно дослідити на екстремум. Для цього його необхідно привести до канонічного виду:

$$
y-y_{c}=\sum_{i=1}^{r} Q_{i} Z_{i}^{2}+\sum_{j=r+1}^{k} C Z_{i} .
$$

Отримане рівняння $Y-Y \mathrm{o}=3.58 Z_{1}^{2}+2.50 Z_{2}^{2}+1.6 Z_{3}^{2}$ дозволяє класифікувати екстремальну крапку "C" і поверхню відгуку.

Поверхня відгуку представлена неповним квадратним рівнянням. Значення $Q_{1}$ і $Q_{2}$ мають однаковий знак, тому центр фігури (екстремальна крапка $C$ ) є мінімумом і має координати 
$X_{1}=0.33 ; X_{2}=0.25 ; X_{3}=0.47$. На рис. 1 представлена досліджувана область глибини вибілення в клиновій пробі залежно від вмісту кальцію й барію при витраті графітизуючого модифікатора від 2,9 до $4,0 \%$.
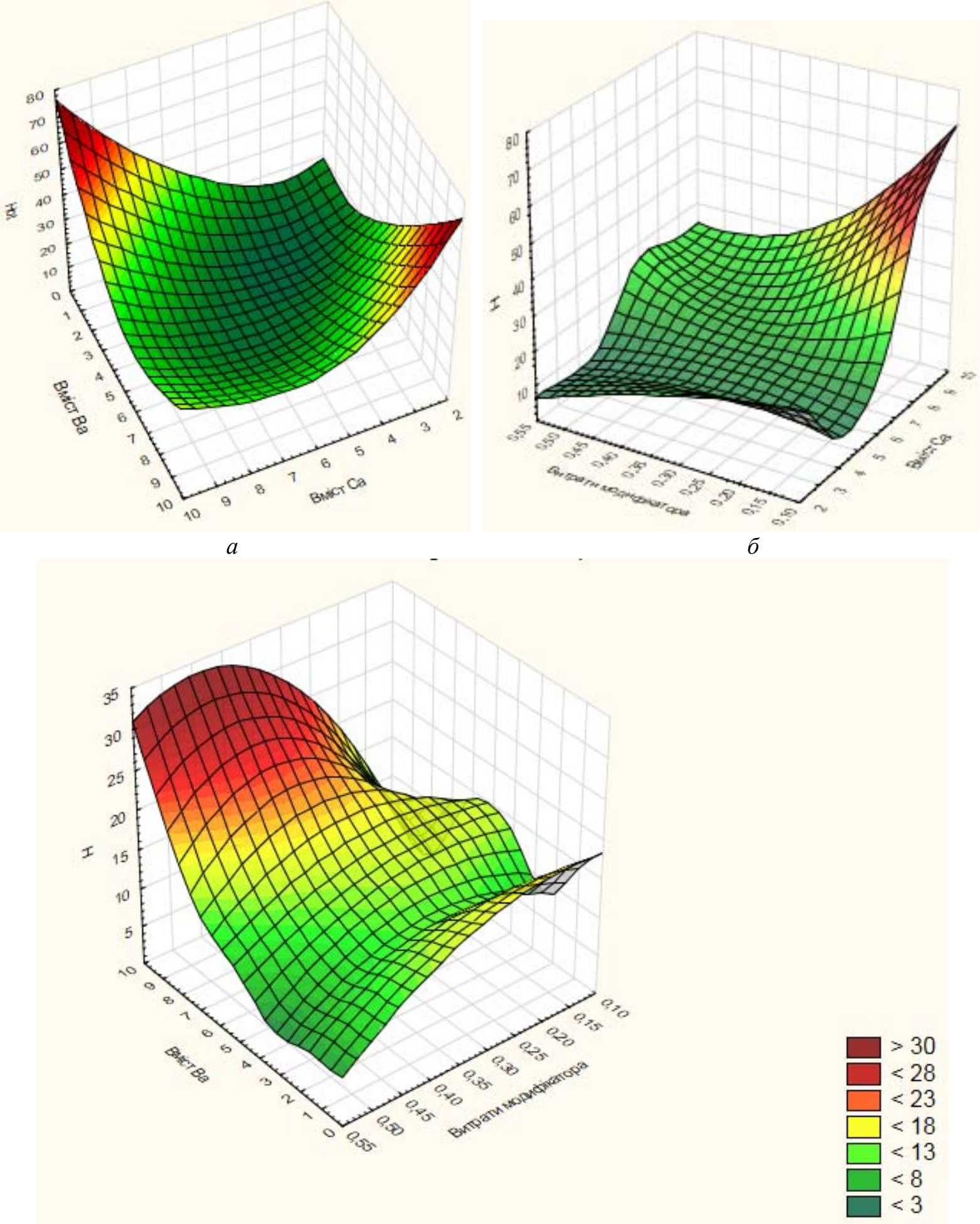

Puc. 1. Вплив Са, Ва і витрат модифікатора на глибину вибілення високоміцного чавуну $a-\mathrm{Ca}$ i Ba; $\sigma-\mathrm{Ca}$ і витрати; $6-\mathrm{Ba}$ і витрати модифікатора 
3 рівняння випливає, що всі фактори знижують глибину вибілення в клиновій пробі. При цьому більший вплив виявляє витрата модифікатора, але через небажаність підвищеного вмісту кремнію в чавуні, умовами експерименту витрата модифікатора була обмежена межею до $0.4 \%$. Права частина рівняння являє собою параболоїд, перетин якого при $X_{3}=$ const, близький до кола. При русі по осях $Z_{1}$ i $Z_{2}$ від точки $C$ глибина вибілення збільшується. Величина коефіцієнтів при факторах $Z_{1}$ i $Z_{2}$ практично однакова, що вказує на рівнозначну величину впливу барію й кальцію на вибілення у цій області факторного простору, тому що інтервали варіювання при проведенні експериментів були однакові $-1 \%$.

Для натуральних значень змінних отримане рівняння регресії можна записати в наступному вигляді:

$$
H_{\text {виб }}=21-6 x_{1}-5.5 x_{2}-4.0 x_{3}+1.1 x_{1} x_{2}+11 x_{2} x_{3}+4 x_{2} x_{3} .
$$

В оптимальному складі графітизуючого модифікатора вміст кальцію більше ніж у півтора рази перевищує вміст барію. При вивченні впливу цих елементів на кінетику графітизації чавуну при охолодженні було показано, що Са виявляє більш інтенсивний вплив при високих температурах, ніж Ва, для якого характерно графітизуючий вплив при евтектичній кристалізації. Тому при спільному впливі внесок Са в процес графітизації більший ніж Ва й більший його вміст у модифікаторі.

На рис. 2 наведена мікроструктура зразків високоміцного чавуну, обробленого графітизуючим модифікатором оптимального складу, вирізаних зі стінок виливка товщиною 6 і 16 мм. Структура чавуну обох зразків перліто-феритна, структурно-вільний цементит відсутній.

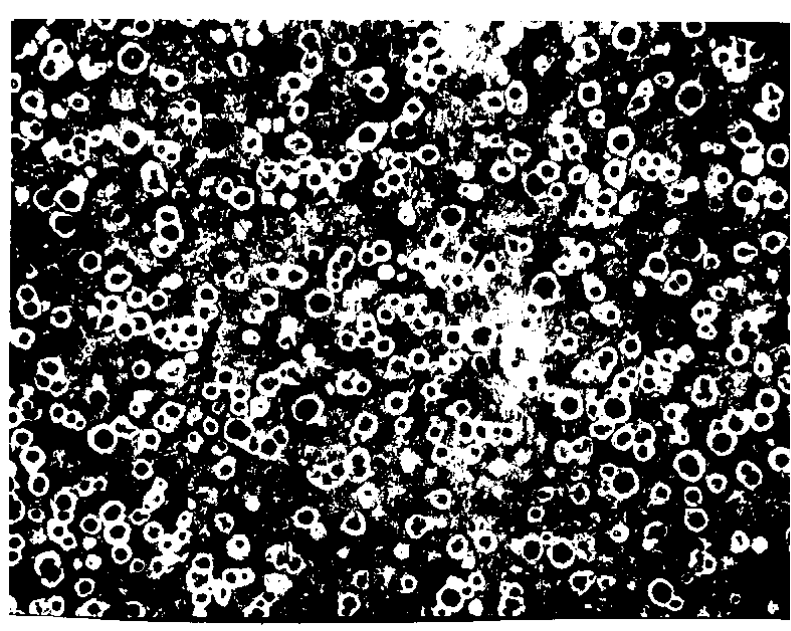

$a$

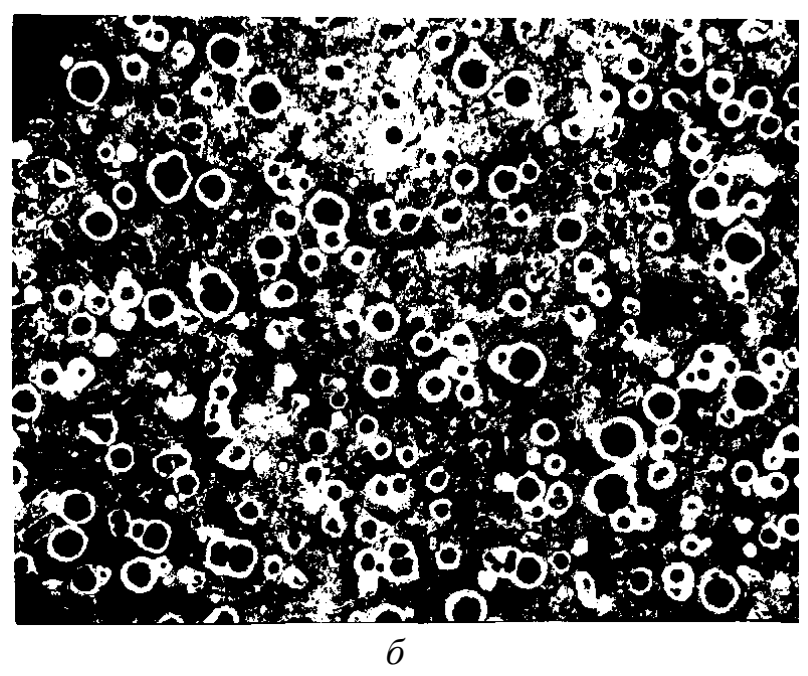

Puc. 2. Структура високоміцного чавуну, обробленого 0,4 \% графітизуючого модифікатора оптимального складу у виливку з товщиною стінки: $a-6$ мм, $\sigma-16$ мм $\times 200$ мм

Порівняно з вихідними зразками в структурі чавуну обробленого графітизуючим модифікатором значно збільшується кількість включень графіту. У зразку товщиною 6 мм кількість включень складає 226, у зразку товщиною 16 мм - 160 шт на міліметр квадратний. Із збільшенням товщини стінки незначно збільшився і діаметр включень графіту з $2-6$ до 3-9 мкм. Структура обох зразків чавуну перліто-феритна 5 \% фериту і 95 \% перліту. Введення до складу залізо-кремнієвого сплаву для вторинного модифікування високоміцного чавуну активних елементів дозволяє підвищити його графітизуючу здатність за рахунок утворення мілкодисперсних включень, які слугують зародками для виділень включень графіту. Це призводить також до різкого збільшення кількості евтектичних зерен і подрібнення графіту. Знижує чутливість чавуну до швидкості охолодження виливків. 


\section{Висновки}

Таким чином, на підставі виконаних досліджень було встановлено, що оптимальний вміст кальцію й барію в графітизуючому модифікаторі для високоміцного чавуну, отриманого сфероідизуючою обробкою $\mathrm{NiMg-лігатурою,} \mathrm{становить} 4.3 \%$ і 2.8 \% відповідно при витраті до $0.4 \%$. Використання графітизуючого модифікатора даного складу при витратах не більше $0,4 \%$ забезпечує отримання виливків із товщиною стінки до бмм без структурно вільного цементит і виключає проведення термічної обробки. Для більш широкого практичного використання результатів роботи необхідно провести додаткові дослідження на високоміцному чавуні отриманого при використанні для первинної обробки залізо-кремній-магнієвого модифікатора.

\section{Список використаної літератури}

1. Еременко А. П. Графитизирующее модифицирование высокопрочного чугуна для тонкостенных отливок / А. П. Еременко, В. А. Брезицька. // Збірник наукових праць ДДТУ (технічні науки). - 2017. - № 2. - С. 16-20.

2. Еременко А. П. Анализ состава промышленного ферросилиция марки ФС75 / А. П. Еременко, И. В. Губарев. // Збірник наукових праць ДДТУ (технічні науки). - 2001. - № 1. - С. 29 33.

3. Адлер Ю. П. Планирование эксперимента при поиске оптимальных условий / Ю. П. Адлер. М: Наука, 1965. - 221 с.

4. Худокормов. Роль примесей в процессе графитизации чугуна / Худокормов. - Минск: Наука и техника, 1968. - $156 \mathrm{c}$.

5. Винарский Н. М. Планирование эксперимента в промышленных исследованиях / Н. М. Винарский, Л. И. Лурье. - К: Техника, 1975. - 236 с.

6. Радченко К.С. Оптимизация химического состава износостойких высоколегированных белых чугунов / К.С.Радченко, Г.Е. Федоров, М.М. Ямшинский // Металл и литье Украины. -2011. № $1 .-$ С. 20-23.

7. Пастухов Т.В. Влияние легирования на температуру превращения «перлит-аустенит» в комплексно-легированных белых чугунах / Т.В. Пастухов, В.Г. Ефременко, А.П. Чейлях // Наука та прогрес транспорту. Вісник ДНУЗТ. 2015. № 1 (55). - С. 113-121.

8. Чигарев В.В. Изменение структуры и свойств литого металла легированием в отливках из чугуна и стали. / В.В. Чигарев, Д.А. Рассохин, А.В. Лоза // Вісник ПДТУ: Збірник наукових праць. - 2010. - Вип 21. С. 61-66.

9. Левченко Ю.Н. Исследование влияния различных вторичных модификаторов на структуру высокопрочных чугунов / Ю.Н.Левченко, Н.Я. Терещенко // Процессы литья - 1994. № 1. C. $54-59$.

10. Берчук Д.Н. Влияние внутриформенного графитизирующего модифицирования на структурообразование высокопрочного чугуна. / Д.Н. Берчук // Процессы литья - 2003. №3. - С. 39-42.

11. Суменкова В.В. Исследование термодинамики реакций взаимодействия активных элементов модификаторов с примесями чугуна. / В.В.Суменкова, Д.Н. Берчук, В.Б. Бубликов // Процессы литья - 2006. № 4. - С. 29-34.

12. Бубликов В.Б. Экспериментальное исследование физико-химческих процессов в «системе плавящийся ферросилиций-чугун» / В.Б. Бубликов, В.П. Латенко, Ю.Д. Бачинский, В.В. Суменкова, Е.П. Нестерук // Процессы литья - 2011. № 5. - С. 9-18. 


\title{
MODELING OF THE OPTIMUM COMPOSITION OF THE MODIFICATOR FOR THE RECEIVING OF HIGH-QUANTITATIVE CUTTINGS WITHOUT MAKING AND THERMAL PROCESSING
} Yeremenko A.P., Kolesnik Ye.V., Sivaeva G.O., Wolf O.O.

\begin{abstract}
One of the characteristic features of high-strength cast iron is the crystallization of a metastable system, which greatly impairs the properties of thin-walled castings of machine-building applications. The presence of free cementite in the structure of the iron is a defective feature for most castings of machine-building purposes, as it significantly increases hardness, which can exceed the permissible limits and complicate the mechanical drawing of cast billets in mechanical workshops. To eliminate this disadvantage - removal of cementite and obtaining the necessary structure of casting undergo graphitizing heat treatment. Conducting heat treatment requires the implementation of additional operations and equipment, production space, extends the production cycle of casting, greatly increases the energy efficiency and cost of casting, which makes it uncompetitive in the market of products. To eliminate these drawbacks, studies were carried out on the production of castings without structurally free cementite in the cast state due to additional graphitizing modification.

For the prevention of crystallization with bleaching in castings, secondary modification with ferrocylic acid FSB5 is used. However, its use in necessary quantities is not always possible due to restrictions on the finite content of silicon in the cast iron. To increase the graphitizing potential of ferroalloys and to reduce its cost can be due to the introduction of graphite elements - A1, Ca, Ba, Ti. REM These elements have a high affinity for the components of the cast iron, even at high temperatures, and the compounds formed can be substrates for the embryos of graphite inclusion. However, there is no clear recommendation that the content of these elements in the secondary modifier is absent. Melting was carried out to optimize the composition of the meliorator using the method of mathematical planning of the experiment.

In order to determine the optimal composition of the graphitizing modifier, a full factor experiment was conducted, calculations and experiments of gradient motion and additional experiments under the second-order orthogonal plan were made to clarify the region of the optimum. The obtained equation allowed to classify the extreme point " $\mathrm{C}$ " and the surface of the response. The surface of the response is represented by an incomplete square equation. The coefficients for variables have the same sign, so the center of the figure, the extreme point $\mathrm{C}$, is the minimum that corresponds to the set goal. The right-hand side of the equation is a paraboloid whose intersection at $\mathrm{X} 3=$ const, is close to the circle. The greater the effect is the expense of the modifier. In the optimal composition of the graphitizing modifier, the content of calcium and barium in the graphitizing modifier for highstrength pig iron is $4.3 \%$ and $2.8 \%$ respectively. In the structure of cast iron processed graphitizing modifier significantly increases the number of graphite inclusions, decreases the diameter of inclusions, reduces the sensitivity of pig iron to the coolness of the cooling.
\end{abstract}

\section{References}

1. Yeremenko, AP., \& Brezitska V.A. (2017). Grafitiziruyushcheye modifitsirovaniye vysokoprochnogo chuguna dlya tonkostennykh otlivok [Graphitizing Modification of HighStrength Cast Iron for Thin-walled Castings]. Zbirnik naukovih prats DDTU (technical science) Collection of scientific works of DGTU (technical sciences), 2, 16-21 [in Ukrainian].

2. Yeremenko, AP., \& Gubarev I.V. (2001). Analysis of the composition of industrial ferrosilicon grade FS75 [Analiz sostava promyshlennogo ferrosilitsiya marki FS75]. Zbirnik naukovih prats DDTU (technical science) - Collection of scientific works of DGTU (technical sciences), 1, 29-33. [in Ukrainian].

3. Adler Yu. P. (1965). Planirovaniye eksperimenta pri poiske optimal'nykh usloviy [Planning of an experiment when searching for optimal conditions]. Moskov: Science [in Rassia].

4. Khudokormov D.N. (1968). Rol' primesey v protsesse grafitizatsii chuguna [The role of impurities in the process of graphitization of iron]. Minsk: Science and technology [in Belarusia]. 
5. Vinarsky N.M., \& Lurie L.I. (1975). Planirovaniye eksperimenta v promyshlennykh issledovaniyakh [Planning an experiment in industrial research]. Kyiv:Teznika [in Ukrainian].

6. Radchenko K.S.\& Fedorov G.E. (2011).Optimizaciya chimicheskogo sostava iznosostoukikh vysokolegirovanykh belykh chugunov [Optimisation of chemical compound of abrasive resistant highly alloyed white pig-iron]. Metal and Ukraine casting, 1, 20-23. [in Ukrainian].

7. Pastukhov T.V. \& Efremenko V.G. (2015). Vliyanie legirovaniya na temperaturu prevracheniya "perlit-austenit" v kompleksno-legirovanikh belikh chugunakh [Influence alloying to temperature of transformation "perlite-austenite" in complex-alloyed white pig-iron]. Science and progress of the transport].Visnik DNUZT. 1 (55),113-121. [in Ukrainian].

8. Chigarev V.V. \& Rassokhin D.A., Loza A.V. (2010) Izmenenie strukturi e svoystv litogo metalla legirovaniem v olivkakh iz chuguna e stali [ Change of the structure and properties of cast metal легированием in casting from pig-iron and became]. VYSNIK PDTU:Zbirnik naukovih prats.Vip 21. 61-66. [in Ukrainian].

9. Levchenko U.N. \& Terechenko N.Y. (1994). Issledovanie vliyaniya razlichnikh vtorichnikh modifikatorov na strukturu visokoprochnikh chugunov [Research of influence of various secondary modifiers to the structure of high-strength pig-iron]. Processes of the casting. 1. 54-59. [in Ukrainian].

10. Berchuk D.N. (2003). Vliyanie vnutriformennogo grafitiziruyuchego modificirovaniya na strukturoobrazovanie visoprochnogo chuguna [Influence of in-uniform grafitiziruyuchego modifying to structurization of high-strength pig-iron]. Processes of the casting. 3, 39-42. [in Ukrainian].

11. Sumenkova V.V. \& Berchuk D.N. (2006). Issledovanie termodinamiki reaktsiy vzaimodeystviya aktivnikh elementov modifikatorov s primecyami chuguna [Research of thermodynamics of reactions of interaction of mechanically active components of modifiers with pig-iron impurityies]. Processes of the casting, 4. 29-34. [in Ukrainian].

12. Bublikov V.B. \& Latenko V.P. (2011). Eksperimentalnoe issledovanie fiziko-khimicheskikh protsesov v "sisteme plavyashchiisya ferrosilitsii-chugun" [Experimental research is physics-chemical processes in "system of melting ferrosilicon -pig-iron]. Processes of the casting, 5, 9-18. [in Ukrainian]. 